\title{
Cattail Mosquito (suggested common name) Coquillettidia perturbans (Walker) (Insecta: Diptera: Culicidae: Culicinae: Mansoniini) ${ }^{1}$
}

\author{
Lethia R. Johnson, James P. Cuda, and Nathan Burkett-Cadena²
}

\section{Introduction}

Approximately 60 species of the genus Coquillettidia Dyar are known worldwide. However, the only species that occurs in North America is the so-called cattail mosquito, Coquillettidia perturbans (Walker) (Figure 1) (BurkettCadena 2013). This particular mosquito is a permanent freshwater species whose larvae and pupae exhibit the unusual habit of attaching to the roots of emergent aquatic plants, especially cattails (hence the suggested common name) (Morris et al. 1990). The biting females can be a nuisance to domestic animals and humans when abundant because they are persistent and painful biters (BurkettCadena 2013). The cattail mosquito is a vector of several important disease-causing organisms that affect humans. It is active principally during the early evening hours, but has been known to seek humans for blood meals in shady places where adult mosquitoes are resting during the day (Carpenter and LaCasse 1955; WRBU 2016).

\section{Synonymy}

Coquillettidia perturbans (Walker 1856) - accepted name

Mansonia (Coquillettidia) perturbans (Walker 1856)

Culex perturbans (Walker 1856)

Culex testaceus (Wulp 1867)

Culex ochropus (Dyar and Knab 1907)

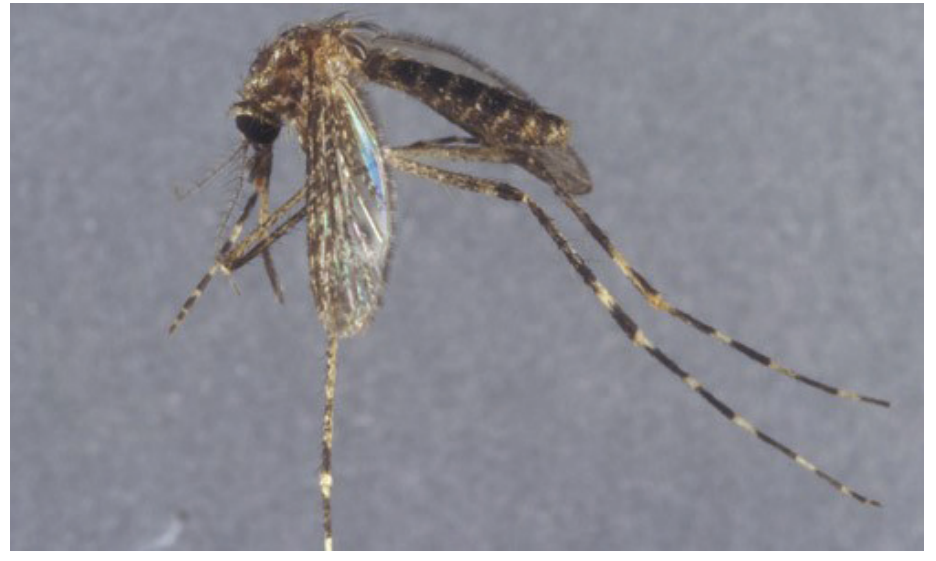

Figure 1. Adult male of Coquillettidia perturbans (Walker). Credits: Lyle J. Buss, UF/IFAS

\section{Distribution}

The cattail mosquito occurs throughout Canada, the United States, and Mexico (Carpenter and LaCasse 1955; WRBU 2016). It is a widely distributed across the eastern half of the US, southern Canada and several areas in the western US (Figure 2, Burkett-Cadena 2013).

1. This document is EENY-694, one of a series of the Department of Entomology and Nematology, UF/IFAS Extension. Original publication date November 2017. Visit the EDIS website at http://edis.ifas.ufl.edu. This document is also available on the Featured Creatures website at http:// entomology.ifas.ufl.edu/creatures.

2. Lethia R. Johnson, Department of Biology; James P. Cuda, professor, Department of Entomology and Nematology; and Nathan Burkett-Cadena, Florida Medical Entomology Laboratory; UF/IFAS Extension, Gainesville, FL 32611. 


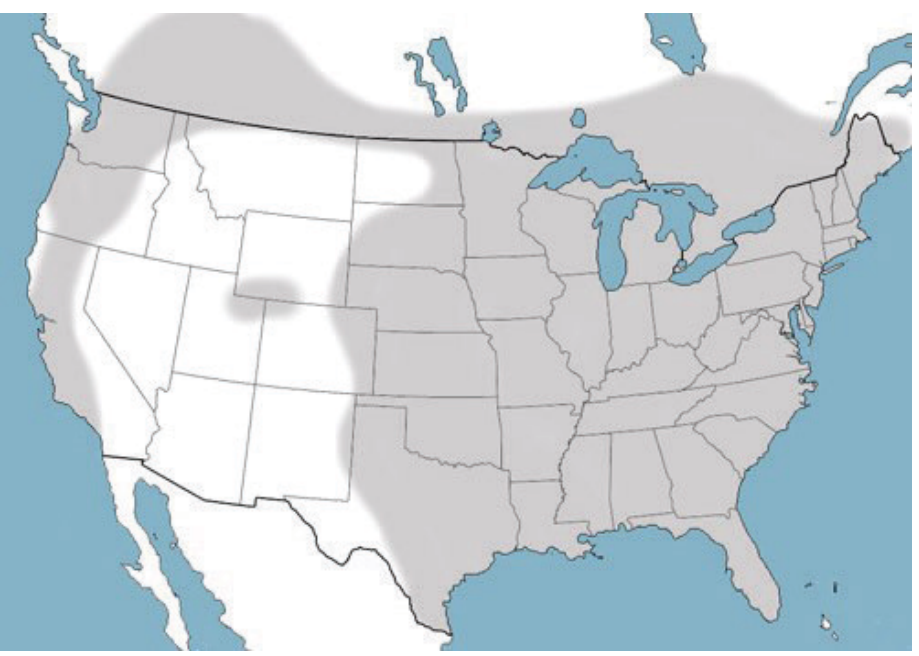

Figure 2. Distribution of the cattail mosquito Coquillettidia perturbans (Walker) in North America. Shaded area indicates the presence of Coquillettidia perturbans.

Credits: Nathan Burkett-Cadena, Florida Medical Entomology Laboratory, UF/IFAS

\section{Description}

\section{Eggs}

Eggs are laid on the surface of the water near emergent vegetation (Carpenter and LaCasse 1955). They are elongate and white in color initially but darken within one to two hours after being laid. Females glue individual eggs together as they are deposited to form a floating raft (Figure 3) (Carpenter and LaCasse 1955; Crisp et al. 2002).

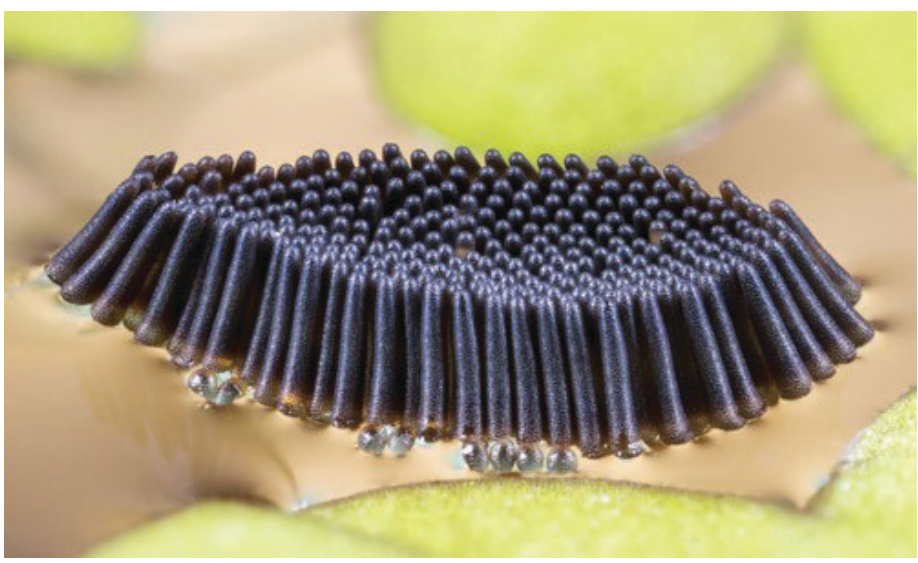

Figure 3. Egg raft of Coquillettidia xanthogaster Edwards, a close relative of the cattail mosquito Coquillettidia perturbans (Walker). Credits: S. L. Doggett, Department of Medical Entomology, NSW, Australia

\section{Larvae}

Mature larvae are grayish white in color and have long, whip-like antennae, each bearing a large, profusely branched bristle (Figure 4 Burkett-Cadena 2013). The head is much wider than it is long, and the comb on the eighth abdominal segment has $8-15$ thorn-shaped scales. Unlike most mosquitoes that obtain oxygen at the water surface via the siphon (air tube), larvae of the cattail mosquito have a heavily sclerotized siphon that resembles a short, pointed saw. The saw-like projections are used to pierce the hollow roots or submersed stems of aquatic plants for respiration (Figures 4 and 5) (Carpenter and LaCasse 1955; BurkettCadena 2013).

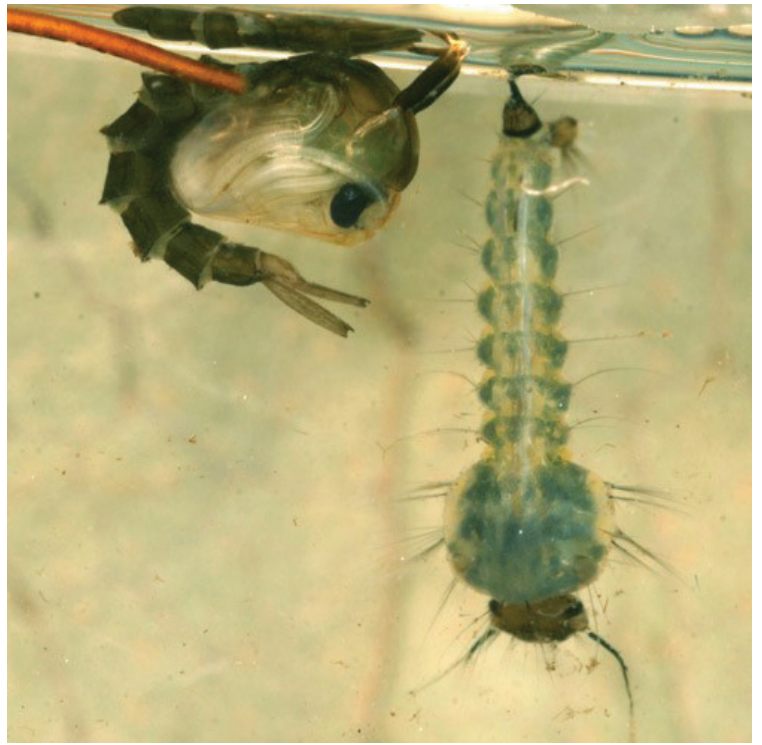

Figure 4. Pupa (left) and larva (right) of the cattail mosquito Coquillettidia perturbans (Walker).

Credits: Nathan Burkett-Cadena, Florida Medical Entomology Laboratory, UF/IFAS

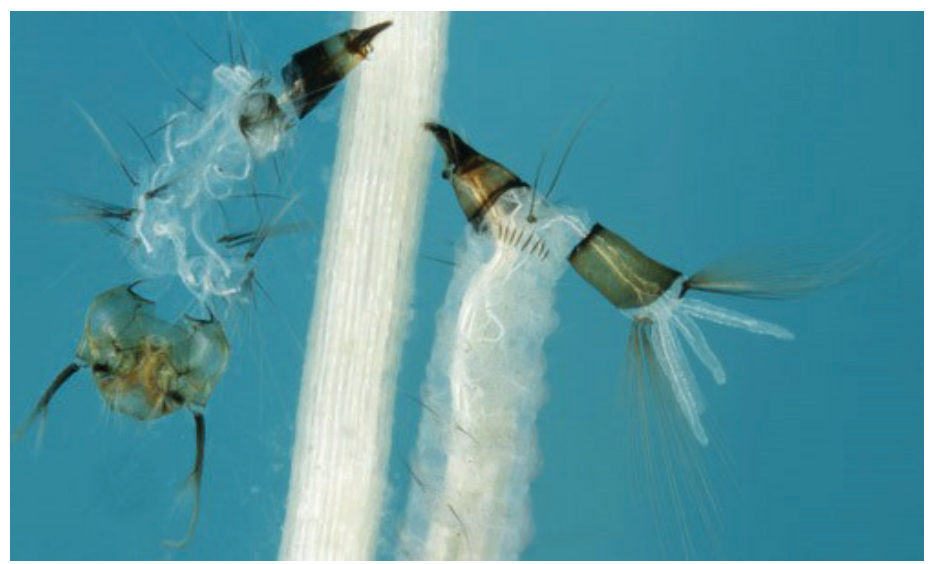

Figure 5. Close up view of siphon and cast skin of Coquillettidia xanthogaster Edwards, a close relative of the cattail mosquito Coquillettidia perturbans (Walker). Notice the thorn-shaped scales on the 8th abdominal segment.

Credits: S. L. Doggett, Department of Medical Entomology, NSW, Australia

\section{Pupae}

Pupae are a non-feeding transitional stage in which the adults complete their development (Figure 4). There are two body regions in the pupal stage, an expanded cephalothorax (fused head and thorax) and an elongated abdomen with eight movable segments terminating in a pair of paddles (Crisp et al. 2002). Two short, flared tubules (trumpets) projecting from the cephalothorax surround the openings to the respiratory system. Pupae of the cattail mosquito 
insert their trumpets into the hollow, air-filled roots or submersed stems of aquatic plants to obtain oxygen.

\section{Adults}

Adults are medium-sized and more or less "salt and pepper" in color due to the presence of broad white, black, and brown scales (Figures 6 and 7). In females, the proboscis is dark scaled with a median band of pale white scales. The dorsal surface of the thorax in males and females has golden brown scales. The abdomen in females is bluntly rounded, and mostly dark scaled with patches of pale scales on each segment. The wings are covered with dark and light broad scales (Burkett-Cadena 2013).

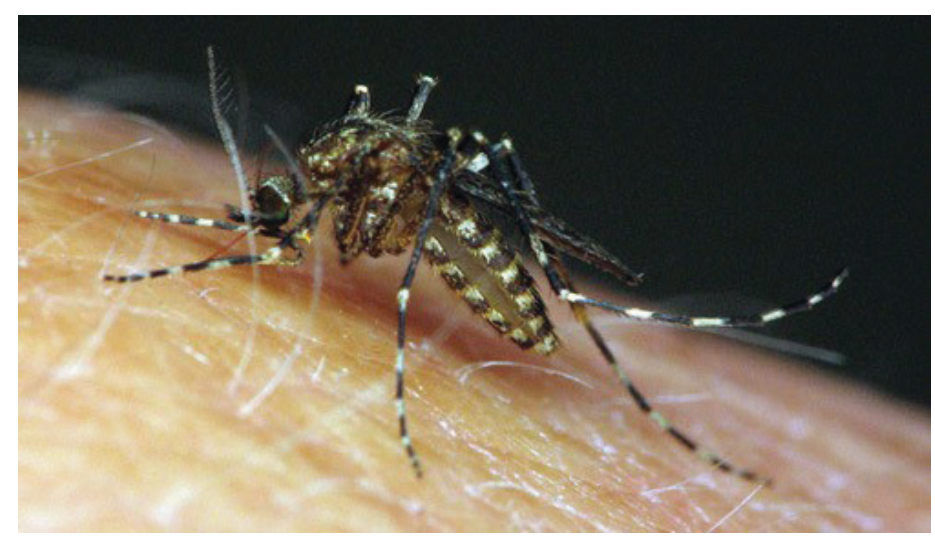

Figure 6. Female of the cattail mosquito Coquillettidia perturbans (Walker) taking a blood meal.

Credits: Sean McCann, Department of Biology, Simon Fraser University, Vancouver, BC, Canada

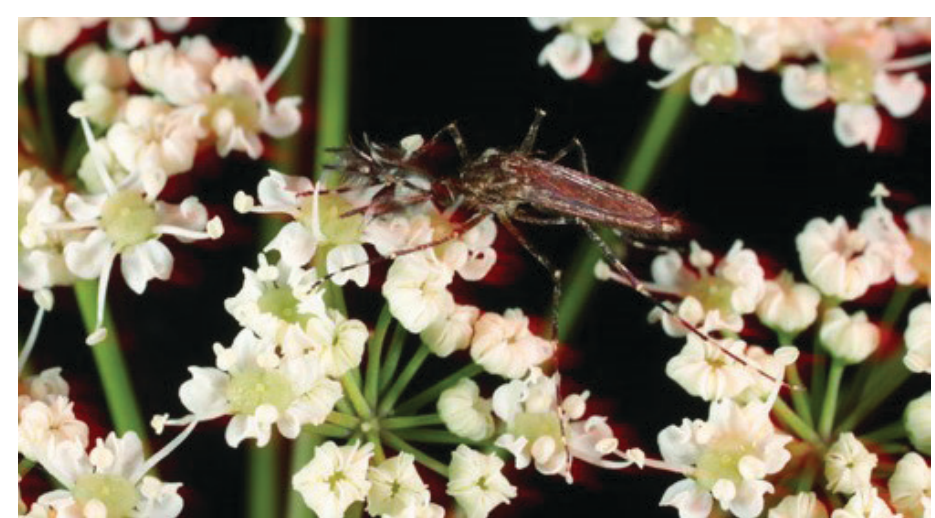

Figure 7. Coquillettidia perturbans (Walker) male feeding on flower nectar.

Credits: Nathan Burkett-Cadena, Florida Medical Entomology Laboratory, UF/IFAS

\section{Life Cycle and Biology}

Females deposit 150-350 eggs on or near the leaves of aquatic plants (Smith and McIver 1984), particularly cattails. Neonates (newly hatched larvae) seek out and attach themselves to the roots or submersed stems of aquatic plants where they remain to complete their development (Carpenter and LaCasse 1955). However, larvae can readily detach and burrow into the sediment if disturbed (Darsie and Hutchinson 2009). They do not need to rise to the surface to breathe like other mosquito larvae because they obtain oxygen directly from the plant. The larval stage has four instars, the durations of which vary greatly depending upon temperature, latitude, and food availability (Lounibos and Escher 1983). The cattail mosquito undergoes an obligatory diapause in the larval stage (Morris et al. 1986). In the northern parts of its range, it overwinters as immature or mature larvae; synchronous emergence of adults generally occurs the following spring or early summer (Carpenter and LaCasse 1955; Lewis and Bennett 1980).

In Florida, adults are present during spring and summer but peak abundance occurs from June to September (Burkett-Cadena 2013). In Canada, the cattail mosquito exhibits a univoltine (one generation) life cycle; the larval stage can last up to nine months (Lewis and Bennett 1980; Allan et al. 1981). In contrast, there are two or three broadly overlapping generations in central Florida (Lounibos and Escher 1983; Morris et al. 1986). The pupal stage of the cattail mosquito is quite variable, lasting up to several weeks. After adults emerge from the pupal stage, the wings will harden within 24 hours, and they will be able to fly soon thereafter (Mullen and Durden 2009). The sex ratio of males and females is approximately 1:1. The life span of the adult cattail mosquito is approximately one to two months with females tending to outlive their male counterparts.

\section{Hosts}

\section{Immature Stages}

In addition to cattails (Typha spp.), larvae and pupae of Coquillettidia perturbans are associated with the roots or submersed stems of many different aquatic plants, including arrowhead (Sagittaria spp.), pickerelweed (Pontederia spp.), water lily (Nymphaea spp.), rushes (Juncus spp.), reeds (Phragmites spp.), sedges (Carex spp.), and water arum (Calla spp.) (Morris et al. 1986). All of these host plants are rooted in thick humus-rich hydric soils.

\section{Adults}

Males feed exclusively on flower nectars (Figure 7) and other plant juices. Females also feed on flower nectar for nutrition, but must also feed on blood, which is essential for egg production (Figure 6). Females of Coquillettidia perturbans (Walker) have been reported to bite and feed on the blood of a wide variety of wild and domestic birds and mammals, including chickens, quail, cattle, rabbits, armadillos, raccoons, opossums, and humans (Edman 1971). 


\section{Medical Importance}

The female cattail mosquito is a vicious biter, capable of penetrating clothing. They also are strong fliers, able to travel up to five miles. In addition to being a nuisance due to their biting behavior, this mosquito is known to transmit two major arboviruses, West Nile virus and eastern equine encephalomyelitis virus (Darsie and Hutchinson 1990; CDC WNV 2015). Although there are equine vaccines for these viruses, currently there are no vaccines available for humans. Protective clothing and mosquito repellent should be used when outdoors to avoid mosquito bites (ENY-671, http://edis.ifas.ufl.edu/in419).

\section{Management}

Because larvae and pupae of Coquillettidia and Mansonia mosquitoes do not need to breathe at the water surface, they are not easy to find in the field and are difficult to control with conventional larvicides. Immature stages can be sampled by pulling up aquatic plants (cattails, sedges, pickerelweed, etc), washing them in a white pan of water, and examining the sediment and debris for the presence of larvae or pupae (Dame and Fasulo 2002; MMCA 2002). Cattails (Typha spp.) are native aquatic plants that often exhibit invasive characteristics due to habitat disturbance. Because they are the preferred developmental host of Coquillettidia perturbans (Walker), removal of excessive cattail growth (source reduction) often is the only effective and economical long-term method of control.

\section{Selected References}

Allan SA, Surgeoner GA, Helson BV, Pengelly DH. 1981. Seasonal activity of Mansonia perturbans adults (Diptera: Culicidae) in southwestern Ontario. Canadian Entomologist 113: 133-139.

Burkett-Cadena ND. 2013. Mosquitoes of the southeastern United States. The University of Alabama Press, Tuscaloosa, Alabama, United States. 188 pp.

Carpenter SJ, LaCasse WJ. 1955. Mosquitoes of North America (North of Mexico), University of California Press, Berkeley, California, USA. 360 pp.

Crisp S, Crisp N, Halstead S, Hughes B, Knepper R, Kight M, Lechell II W, McCarry M, McGeachy B, Mohsen Z, Newton D, Patterson J, Poplar M, Putt T, Pylar M, Stenske M, Seago G, Walker E, Wilmot T, Breasbois M. 2002. Michigan Mosquito Manual, MMCA Edition (Michigan Mosquito Control Association), June 2002. Michigan
Department of Agriculture \& Rural Development, Lansing, Michigan, USA 109 pp. (22 November 2017)

Centers for Disease Control West Nile Virus (CDC WNV). 2015. List of mosquitoes in which West Nile virus has been detected. http://www.cdc.gov/westnile/transmission/index. html

Dame DA, Fasulo TR. 2002. Public-Health Pesticide Applicator Training Manual, SP318, Chapter 3. UF/IFAS. http://entnemdept.ufl.edu/fasulo/vector/manual.htm

Darsie RF, Hutchinson ML. 2009. The Mosquitoes of Pennsylvania. Technical Bulletin \#2009-001 of the Pennsylvania Vector Control Association. 191 pp.

Edman JD. 1971. Host-feeding patterns of Florida mosquitoes I. Aedes, Anopheles, Coquillettidia, Mansonia and Psorophora. Journal of Medical Entomology 8: 687-695.

Integrated Taxonomic Information System (ITIS). 2017. https://www.itis.gov/ (13 November 2017).

Lewis DJ, Bennett GF. 1980. Observations on the biology of Mansonia perturbans (Walker) (Diptera: Culicidae) in the Nova Scotia-New Brunswick border region. Canadian Journal Zoology 58: 2084-2088.

Lounibos LP, Escher RL. 1983. Seasonality and sampling of Coquillettidia perturbans (Diptera: Culicidae) in south Florida. Environmental Entomology 4: 1087-93.

Morris CD, Callahan JL, Lewis RH. 1990. Distribution and abundance of larval Coquillettidia perturbans in a Florida freshwater marsh. Journal of the American Mosquito Control Association 6: 452-460.

Morris CD, Slaff M, Parsons R, Haefner JD, Callihan JL, Bailey D, Kline D, Nemjo J, McClain K. 1986. Investigations of Methodologies for Management of Mosquito Populations in Phosphate Mining Areas. Florida Institute of Phosphate Research, 03-015-043. 174 pp.

Mullen GR, Durden LA (Eds.). 2009. Medical and Veterinary Entomology, Second Edition. Elsevier, Inc., Burlington, MA. 637 pp.

Smith BP, McIver SB. 1984. The impact of Arrenurus danbyensis Mullen (Acari: Prostigmata; Arrenuridae) on a population of Coquillettidia perturbans (Walker) (Diptera: Culicidae). Canadian Journal of Zoology 62: 1121-34. 
Walter Reed Biosystematics Unit. 2016. Coquillettidia (Coq.)

perturbans. http://www.wrbu.org/mqID/mq_medspc/AD/

CQper_hab.html 